\title{
Seasonal variation in cell cycle during early development of the mouse embryo
}

\section{Jiann-Ping Wang ${ }^{1}$, Wann-Yee Her ${ }^{1}$, Yaa-Jyuhn Meir ${ }^{1}$, Ts'an-Shiuu Liu ${ }^{2}$, Hsiu-Luan Chang ${ }^{3}$ and Fore-Lien Haung ${ }^{4}$}

'Department of Biology, National Cheng Kung University, Tainan, Taiwan, Republic of China; ${ }^{2}$ Department of Anatomy, Kaohsiung Medical College, Kaohsiung, Republic of China; ${ }^{3}$ Department of Animal Breeding, Taiwan Livestock Research Institute, Tainan, Republic of China; and ${ }^{4}$ Institute of Biological Chemistry, Academica Sinica, Taipei, Republic of China

\begin{abstract}
Summary. Studies of the cell cycle of mouse embryos before implantation were conducted using Giemsa and DAPI stains. The time of embryo recovery did not affect the success rate of cultures during the winter, but embryos cultured during the summer showed the 'two-cell block' phenomenon at the early two-cell stage, $30-37 \mathrm{~h}$ after the injection of human chorionic gonadotrophin. There was no significant difference in the number of embryos collected per mouse between summer and winter, but cleavage from the two-cell to the four-cell stage occurred later in the summer than in the winter. Cell cycle of mouse embryos may therefore show seasonal variation.
\end{abstract}

Keywords: two-cell block; seasonal variation; mouse; embryo culture

\section{Introduction}

Many studies have revealed the relationship between DNA replication and morphogenetic events during early mouse embryogenesis (Luthardt \& Donahue, 1973, 1975; Abramczuk \& Sawicki, 1975; Holliday \& Pugh, 1975; Siracusa et al., 1975; Sawicki et al., 1978; Johnson et al., 1984; Howlett \& Bolton, 1985). Several papers have reported embryonic cleavage rates (Bowman \& McLaren, 1970; Gamow \& Prescott, 1970; Allen \& McLaren, 1971; McLaren \& Bowman, 1973; Mukherjee, 1976; Krishna \& Generoso, 1977; Streffer et al., 1980; Goddard \& Pratt, 1983; Newport \& Kirschner, 1984; Aimar, 1988; Houliston et al., 1988), but only endogenous maternal and genetic events have been taken into account (Allen \& McLaren, 1971; Nicol \& McLaren, 1974; Goddard et al., 1983; Molls et al., 1983; Newport \& Kirschner, 1984; Aimar, 1988; Houliston et al., 1988), and the scope has been limited to the first two or three cleavages, when cell number can be estimated by direct inspection (Domon, 1983). The cleavage rate of embryos also depends on the genotype of the mother (Longo \& Anderson, 1969; McLaren \& Bowman, 1973).

Seasonal reproductive behaviour is a well-documented phenomenon in many mammalian species (Laguchev, 1958; Elbling, 1975; Watson \& Chaykin, 1987), but there have been relatively few reports dealing with the effects of the external environment on the cell cycle and developmental programme in the laboratory mouse (Mus musculus) during early cleavage. Several papers have reported that cultured embryos show a block to development at the early two-cell stage $(30-37 \mathrm{~h}$ after human chorionic gonadotrophin (hCG)) (Biggers et al., 1962; Abramczuk et al., 1977; Goddard \& Pratt, 1983; Loutradis et al., 1987). In an extensive series of cultures of embryos recovered from virgin ICR mice over a period of four years (1988-91), we have found that, from July to September, it is very difficult to obtain consistently successful cultures from two-cell to blastocyst stages. Cleavage was slower during the summer than during the winter. 


\title{
Materials and Methods
}

\begin{abstract}
Animals
Institute for Cancer Research (ICR) mice were bred in a room in which temperature and lighting were not controlled artificially, but varied with the seasons. The daylight period was over $14 \mathrm{~h}$ in summer and $10 \mathrm{~h}$ in winter, the mean monthly relative humidity was $85 \%$ in summer and $77.5 \%$ in winter, the mean temperature was $30^{\circ} \mathrm{C}$ in summer and $17.5^{\circ} \mathrm{C}$ in winter.
\end{abstract}

\section{Collection of embryos}

Six-twelve-week-old mice were superovulated by a 5 i.u. injection of pregnant mares' serum gonadotrophin (PMSG) (PEAMEX: Zoki Co. Ltd, Tokyo, Japan) and this was followed by a 5 i.u. injection of hCG (Gona-500: China Chemical \& Pharmaceutical Co. Ltd, Taipei, Taiwan) $48 \mathrm{~h}$ later. At the time of the second injection, the females were placed with males, and they were examined for vaginal plugs on the following morning.

Females were killed by cervical dislocation and embryos were collected into phosphate-buffered saline (PBS) with $1 \%$ fetal cord serum at specific times after hCG injection, rinsed twice, and then transferred to the culture medium described by Whittingham (1971). To obtain one- to eight-cell embryos, oviducts were removed at intervals from 24$60 \mathrm{~h}$ after hCG and the ampulla nicked with a cataract knife at the point of distension. Eight-cell embryos and morulae were obtained $60 \mathrm{~h}$ after hCG by inserting a 30-gauge needle through the wall of the uterus at the tubal end and flushing the uterine lumen with PBS.

\section{Embryo culture}

All embryos were cultured in Petri dishes with $0.05 \mathrm{ml}$ of freshly prepared culture medium (Whittingham, 1971), pre-equilibrated overnight at $5 \% \mathrm{CO}_{2}$ in air, $37^{\circ} \mathrm{C}$, $\geqq 95 \%$ humidity at $\mathrm{pH} 7 \cdot 3-7.4$ under liquid paraffin (Brinster, 1965). Bovine serum albumin (BSA) (Sigma Chemical Co., Poole, Dorset, UK) was added at $4 \mathrm{mg} \mathrm{ml}^{-1}$ before sterile filtration.

\section{Giemsa staining}

One-cell embryos were treated with hyaluronidase in $2 \%$ sodium citrate to remove the follicular cells. Embryos were assessed for normality by their morphology and expected developmental stage. The denuded embryos were washed in fresh $2 \%$ citrate and treated with a hypotonic solution of $0.7 \%$ sodium citrate for $3 \mathrm{~min}$. After excessive solution was removed, about $0.1 \mathrm{ml}$ of $25 \%$ acetic acid in ethanol was added to the slide to cover the embryos. The airdried preparations were placed in $25 \%$ acetic acid in alcohol for $10 \mathrm{~min}$. Fixed preparations were stained with $10 \%$ Giemsa stain for $30 \mathrm{~s}$.

\section{DAPI stain and determination of number of nuclei per embryo}

4',6'-Diamidino-2-phenylindole (DAPI) is used as a fluorescent dye for nuclear stain. Embryos fixed on glass slides were stained with DAPI solution (Hamada \& Fujita, 1983) for $15 \mathrm{~min}$ at room temperature. Finally, the slide was washed with the same PBS and the edge of the coverslip was sealed with nail polish. Fluorescence-emitting embryos were photographed with a Zeiss model epi-illuminated fluorescent microscope for DAPI stained slides.

\section{Counting cell number}

The mean number of cells per embryo was counted directly with the inverted microscope before $55 \mathrm{~h}$ after hCG treatment (embryos less than four cells) and evaluated by DAPI stain after $55 \mathrm{~h}$ after hCG (embryo more than four cells). The number of cell nuclei was taken as the equivalent of the cell number.

\section{Statistical analysis}

All traits studied were described by general linear models and analysed using analysis of covariance. Year and season effects were included as qualitative factors, and time after hCG injection as quantitative factor. Polynomial regression models with one independent variable, that is the time of collecting embryos after hCG injection, were used to analyse the data within seasons.

Chi-square analysis was used to test whether the percentage of embryos from two-cell to four-cell stage is independent of season at different times after hCG injection. 


\section{Results}

\section{Collection of embryos}

A total of 4273 embryos from 382 females was recovered at various times after ovulation. Three thousand six hundred and seventy four embryos were viable while 599 embryos were dead. The numbers of mice and embryos investigated was 156 and 1895 in summer, 226 and 2378 in winter, respectively. There was no significant difference in the average number of embryos collected per mouse between summer (14.8 $\pm 1 \cdot 2)$ and winter $(11.6 \pm 1 \cdot 1)$ using least-squares estimates.

In the one- and two-cell stages, there were significant differences $(P<0.05)$ in terms of percentages between seasons and the corresponding least-squares estimates were $(33 \cdot 3 \pm 3 \cdot 0 \%$, $66.5 \pm 3.0 \%)$ and $(23.9 \pm 2.8 \%, 76 \cdot 1 \pm 2 \cdot 8 \%)$ for summer and winter, respectively. However, the significant effects of seasons on embryo development vanished at later stages $(P>0.05)$.

\section{The first cell cycle}

The number of nuclei per embryo was examined either by phase-contrast microscopy, DAPI staining or Giemsa staining.

The first polar body is extruded from the primary oocyte $12 \mathrm{~h}$ after hCG, which is also the time of ovulation. The chromosomes of the second maturation division are aggregated on the metaphase plate $18 \mathrm{~h}$ after hCG. The sperm nucleus swells and its chromatin begins to decondense very rapidly as the sperm is incorporated and the male pronucleus formation begins. Both pronuclei form at $18-28 \mathrm{~h}$ after $\mathrm{hCG}$ and migrate centrally. Five to six hours after pronuclear formation, the embryos enter the second cell cycle (i.e. the first cleavage division) and the entire first cell cycle is completed by $33.3 \mathrm{~h}$ after hCG treatment in winter and $42.6 \mathrm{~h}$ after hCG treatment in summer.

\section{Two-cell embryo culture}

The number of embryos developing from the two- to four-cell stage was significantly different in winter and in summer, up to $37 \mathrm{~h}$ after hCG (Table 1). However, the level of significance decreased with time and no significant difference was observed at $42 \mathrm{~h}$ after hCG. In summer, two-cell embryos showed a 'two-cell block' if they were collected $30-37 \mathrm{~h}$ after hCG, but no block was found if embryos were collected $42 \mathrm{~h}$ after hCG.

Table 1. Relationship between the proportion of embryos developing from two-cell to four-cell stages and the time of collection during winter and summer

\begin{tabular}{lcccccc}
\hline \multirow{2}{*}{$\begin{array}{l}\text { Time after } \\
\text { hCG injection when } \\
\text { embryos collected } \\
\text { (h) }\end{array}$} & $\begin{array}{c}\text { No. of } \\
\text { embryos } \\
\text { in culture }\end{array}$ & $\begin{array}{c}\text { No. of embryos } \\
\text { developing to } \\
\text { four-cell stage }\end{array}$ & $\begin{array}{c}\text { No. of } \\
\text { embryos } \\
\text { in culture }\end{array}$ & $\begin{array}{c}\text { No. of embryos } \\
\text { developing to } \\
\text { four-cell stage }\end{array}$ & $\begin{array}{c}\chi^{2} \\
\text { (Summer versus winter) }\end{array}$ \\
\hline 30 & 46 & 32 & 37 & 4 & $28 \cdot 83^{* *}$ \\
31 & 80 & 54 & 168 & 36 & $49 \cdot 76^{* *}$ \\
33 & 97 & 53 & 62 & 12 & $19 \cdot 50^{* *}$ \\
37 & 122 & 86 & 37 & 18 & $5 \cdot 98^{*}$ \\
42 & 49 & 37 & 33 & 23 & $0 \cdot 34$ \\
46 & 31 & 26 & 40 & 31 & $0 \cdot 45$ \\
\hline
\end{tabular}

${ }^{* *}: P<0.01 ; *: P<0.05$. 


\section{The second and third cell cycles}

A comparison of the rates of cleavage of the 4273 embryos collected from summer and winter time is given (Fig. 1). From the fitted regression equations, the times after hCG required for at least $50 \%$ of embryos to reach the two-, four- and eight-cell stages are calculated as 37,58 and $71 \mathrm{~h}$, and 35,52 and $67 \mathrm{~h}$, for summer and winter, respectively.

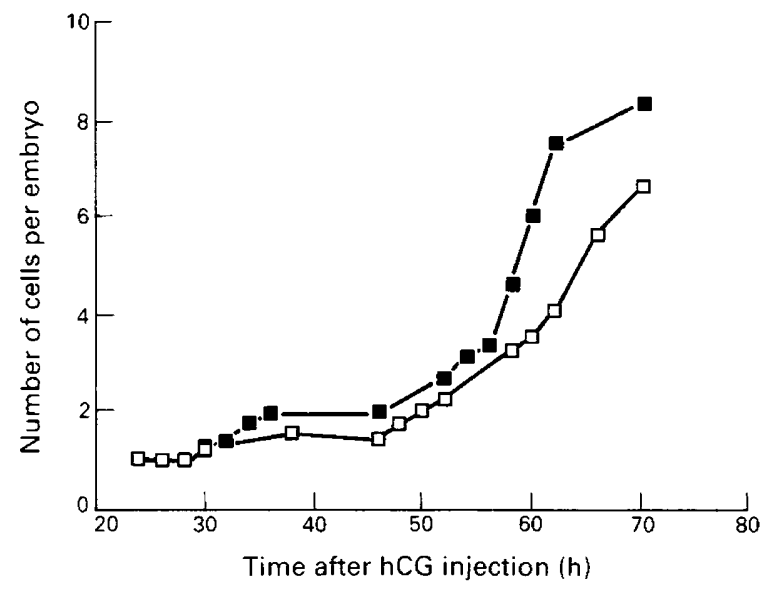

Fig. 1. The growth curves of embryos in relation to time after hCG injection in summer $(\square)$ and in winter $(\mathbf{0})$.

\section{Discussion}

The number of embryos recovered was similar in summer and winter. Our data on the timing of maturation divisions, ovulation, fertilization and the first cleavage division are similar to those in previous studies (Edwards \& Gates, 1959; Donahue, 1968, 1972a,b; Kaufman, 1973), but we found that embryos need a longer time to reach the four-and eight-cell stage in summer than in winter. Seasonal conditions are an important factor in the first two cleavage divisions.

We also found an effect of the time of embryo collection on early embryonic development in summer and winter. Embryos collected $30-37 \mathrm{~h}$ after hCG during the summer showed a 'two-cell block', but those collected later than $40 \mathrm{~h}$ after hCG showed no such block. No 'two-cell block' was observed during the winter, even for embryos recovered $30-37 \mathrm{~h}$ after hCG.

Seasonal effects on reproductive behaviour are a well-documented phenomenon in many mammalian species (Laguchev, 1958; Elbling, 1975; Watson \& Chaykin, 1987). It has been suggested that ovarian inactivity (Legan et al., 1977; Armstrong et al., 1986) and insufficient production of gonadotrophin-releasing hormone GnRH (Hart et al., 1984) may be the prime factors responsible for seasonal variation. In our study, mice were bred in a room where the environmental factors were not artificially controlled. In summer, the temperature and humidity were higher and day length was greater than in winter. We have tested the effect of day length on embryonic development. When the mice were treated with a short daylight period ( $10 \mathrm{~h}$ light:14 h dark) during summer time, their embryos showed a significantly greater chance of progressing from two-cell to four-cell than embryos obtained from untreated mice (data not shown). We have not yet studied the effect of temperature and relative humidity.

We thank Winton T. K. Cheng and T. T. Shu for providing help with experiments and to C. L. Shen for his valuable comments and criticisms. 


\section{References}

Abramczuk, J. \& Sawicki, W. (1975) Pronuclear synthesis of DNA in fertilized and parthenogenetically activated mouse eggs. Exp. Cell Res. 92, 361-372.

Abramczuk, J., Solter, D. \& Koprowski, H. (1977) The beneficial effect of EDTA on development of mouse one-cell embryos in chemically defined medium. Devl Biol. 61, 378-383.

Allen, J. \& McLaren, A. (1971) Cleavage rate of mouse eggs from induced and spontaneous ovulation. $J$. Reprod. Fert. 27, 137-140.

Aimar, C. (1988) Control of cell cycle length in amphibian eggs: evidence for a temporal relationship between the nucleus and egg cytoplasm. Development $104,415-422$.

Armstrong, J.D., Britt, J.H. \& Cox, N.M. (1986) Seasonal differences in function of the hypothalamichypophysial-ovarian axis in weaned primiparous sows. J. Reprod. Fert. 78, 11-20.

Biggers, J.D., Gwatkin, R.B.L. \& Brinster, R.L. (1962) Development of mouse embryos in organ culture of fallopian tubes on a chemically defined medium. Nature 194, 747.

Bowman, P. \& McLaren, A. (1970) Cleavage rate of mouse embryos in vivo and in vitro. J. Embryol. exp. Morph. 24, 203-207.

Brinster, R.L. (1965) Studies on the development of mouse embryos in vitro. IV. Interaction of energy sources. J. Reprod. Fert. 10, 227-240.

Domon, M. (1983) A changing pattern of the cell cycle during the first two cleavage division of the mouse. Dev. Growth Differ. 25, 537-545.

Donahue, R.P. (1968) Maturation of the mouse oocyte in vitro. I. Sequence and timing of nuclear progression. J. exp. Zool. 169, 237-250.

Donahue, R.P. (1972a) Fertilization of the mouse oocytes: sequence and timing of nuclear progression in the two-cell stage. J. exp. Zool. 180, 305-318.

Donahue, R.P. (1972b) Cytogenetic analysis of the first cleavage division in mouse embryos. Proc. Natl Acad. Sci. USA 69, 74-77.

Edwards, R.G. \& Gates, A.H. (1959) Timing of the stages of the maturation divisions, ovulation, fertilization and the first cleavage of eggs of adult mice treated with gonadotrophins. J. Endocr. 18, 292-304.

Elbling, L. (1975) Congenital malformations in mice after gonadotropin-induced ovulation. Proc. Soc. exp. Biol. Med. 149, 376-379.

Gamow, E.I. \& Prescott, D.M. (1970) The cell life cycle during early embryogenesis of the mouse. Exp. Cell Res. 59, $117-123$.

Goddard, M.J. \& Pratt, H.P.M. (1983) Control of events during early cleavage of the mouse embryo: an analysis of the '2-cell block'. $J$. Embryol. exp. Morph. 73, $111-133$.

Hamada, S. \& Fujita, S. (1983) DAPI staining improved for quantitative cytofluorometry. Histochemistry 79 , $219 \cdots 226$.

Hart, P.J., Squires, E.L., Imel, K.J. \& Nett, T.M. (1984) Seasonal variation in hypothalamic content of gonadotropin releasing hormone $(\mathrm{G} n \mathrm{RH})$, pituitary receptors for $\mathrm{GnRH}$ and pituitary content of luteiniz- ing hormone and follicle-stimulating hormone in the mare. Biol. Reprod. 30, 1055-1062.

Holliday, R. \& Pugh, J.E. (1975) DNA modification mechanisms and gene activity during developing. Science 187, 226-232.

Houliston, E., Guilly, M.N., Courvalin, J.C. \& Maro, B. (1988) Expression of nuclear lamins during mouse preimplantation development. Development 102, 271-278.

Howlett, S.K. \& Bolton, V.N. (1985) Sequence and regulation of morphological and molecular events during the first cell cycle of mouse embryogenesis. $J$. Embryol. exp. Morph. 87, 175-206.

Johnson, M.H., McConnell, J. \& Blerkom, J.V. (1984) Programmed development in the mouse embryo. $J$. Embryol. exp. Morph. 83, 197-231.

Kaufman, M.H. (1973) Timing of the first cleavage division of the mouse and the duration of its component stages: a study of living and fixed eggs. J. Cell Sci. 12, 799-808.

Krishna, M. \& Generoso (1977) Timing of sperm penetration, pronuclear formation, pronuclear DNA synthesis, and first cleavage in naturally ovulated mouse eggs. J. exp. Zool. 202, 245-252.

Laguchev, S.S. (1958) Comparison of the estrous cycles in mice of high and low cancer lines. Bull. Exp. Biol. Med. 48, 1149-1152.

Legan, S.L., Karsch, F.J. \& Foster, D.L. (1977) The endocrine control of seasonal reproductive function in the ewe: a marked change in response to the negative feedback action of estradiol in luteinizing hormone secretion. Endocrinology 101, 818-824.

Longo, F.J. \& Anderson, E. (1969) Cytological events leading to the formation of the two-cell stage in the rabbit: association of the maternally and paternally derived genomes. J. Utrastruct. Res. 29, 86-118.

Loutradis, D., John, D. \& Kiessling, A. (1987) Hypoxanthine causes a 2-cell block in random-bred mouse embryos. Biol. Reprod. 37, 311-316.

Luthardt, F.W. \& Donahue, R.P. (1973) Pronuclear DNA synthesis in mouse eggs. Exp. Cell Res. 82, 143-151.

Luthardt, F.W. \& Donahue, R.P. (1975) DNA synthesis in developing two-cell mouse embryos. Devl Biol. 44, $210-216$.

McLaren, A. \& Bowman, P. (1973) Genetic effects on the timing of early development in the mouse. $J$. Embryol. exp. Morph. 30, 491-498.

Molls, M., Zamboglou, N. \& Streffer, C. (1983) A comparison of the cell kinetics of pre-implantation mouse embryos from two different mouse strains. Cell Tissue Kinet. 16, 277--283.

Mukherjee, A.B. (1976) Cell cycle analysis and Xchromosome inactivation in the developing mouse. Proc. Natl Acad. Sci. USA 73, 1608-1611.

Newport, J.W. \& Kirschner, M.W. (1984) Regulation of the cell cycle during early Xenopus development. Cell 37, 731742 .

Nicol, A. \& McLaren, A. (1974) An effect of the female genotype on sperm transport in mice. $J$. Reprod. Fert. 39, $421-424$. 
Sawicki, W., Abramczuk, J. \& Blaton, O. (1978) DNA synthesis in the second and third cell cycles of mouse preimplantation development: a cytophotometric study. Exp. Cell Res. 112, 199-205.

Siracusa, G., Coletta, M. \& Monesi, V. (1975) Duplication of DNA during the first cell cycle in the mouse embryo. J. Reprod. Fert. 42, 395-398.

Streffer, C., van Beuningen, D., Molls, M., Zamboglou, N. \& Schulz, S. (1980) Kinetics of cell proliferation in the pre-implanted mouse embryo in vivo and in vitro. Cell Tissue Kinet. 13, 135-143.

Watson, J.G. \& Chaykin, S. (1987) Seasonal variation in estrous cycling in the mouse: implications for artificial insemination. Devl Biol. 16, 171-176.

Whittingham, D.G. (1971) Culture of mouse ova. $J$. Reprod. Fert. Suppl. 14, 7-21.

Received 15 January 1991 